\title{
usm

\section{Representações Sociais de Trabalhadores com Baixa Escolaridade, Informais e Desempregados sobre a Escolarização}

Social Representations of informal workers, with low education and unemployed in the schooling process

\section{* Ademir José Rosso}

Professor doutor na Universidade Estadual de Ponta Grossa, Paraná, Brasil. ajrosso@uepg.br - http://orcid.org/0000-0002-7143-0433

** Bruna Emilyn da Silva

Mestranda na Universidade Estadual de Ponta Grossa, Paraná, Brasil. bruna.emilyn@hotmail.com

*** Vânia de Oliveira

Professora da Educação Básica de Rede Municipal de Ensino e da Faculdade Santa Amélia, Paraná, Brasil.

solvania@hotmail.com

**** Paulo Rogério Moro

Professor doutor na Universidade Estadual de Ponta Grossa, Paraná, Brasil. paulomoro@uepg.br

***** Franciely Ribeiro dos Santos

Pós-doutoranda na Universidade Estadual de Ponta Grossa, Paraná, Brasil. francielyribeirosantos@gmail.com

Recebido em 31 de maio de 2018

Aprovado em 17 de novembro de 2018

Publicado em 11 de setembro de 2019

\section{RESUMO}

$\mathrm{O}$ artigo analisa as representações sociais (RS) de trabalhadores $(\mathrm{N}=145)$ com baixa escolaridade, informais e desempregados sobre a escolarização. A abordagem teórica das RS é a dimensional de Moscovici associada às discussões sobre escolarização parental. As informações foram coletadas em entrevistas semiestruturadas sobre escolarização pessoal e de seus filhos. Os softwares Alceste e Nvivo e a análise de conteúdo foram utilizados no tratamento das informações para descrever as atitudes, conhecimentos e imagens sobre a escolarização. A produção discursiva formou quatro classes: educação escolar e familiar; interações com a escola; contingências na escolarização; conquistas pessoais e familiares na escolarização. O contexto social e das experiências pessoais dos participantes da pesquisa e de seus filhos com a 


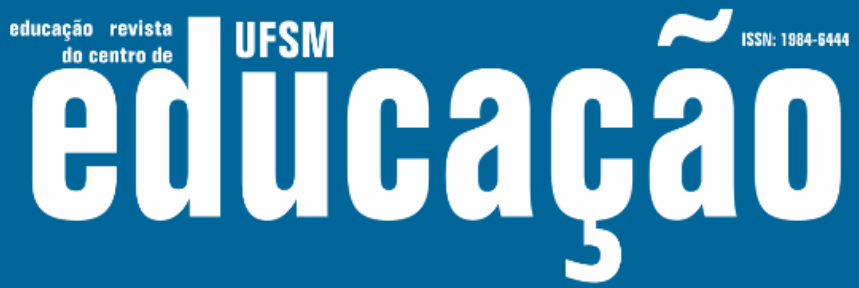

ISSN: 1984-6444 | http://dx.doi.org/10.5902/1984644432852

escola indicam a formação de três representações sociais. A escolarização como: utilidade subordinada às necessidades e projetos familiares ligadas ao trabalho; como complemento ao processo educacional doméstico voltado aos aspectos morais e dos cuidados parentais; e, como correção e disciplinamento para o convívio social.

Palavras-chave: Escolarização; Pais trabalhadores; Relação emprego-escolaridade.

\section{ABSTRACT}

The article analyzes the social representations $(S R)$ of informal workers $(N=145)$, with low education and unemployed in the schooling process. The theoretical approach of $\mathrm{SR}$ is the dimension of Moscovici associated to the discussions about parental schooling. The theoretical approach of SR and the Moscovici dimension associated the discussions about the parents's representation of schooling. The information was collected in semi-structured interviews about personal schooling and their children. Alceste and Nvivo software and content analysis were used in the treatment of information to describe attitudes, knowledge and representations about schooling. Discursive production formed four classes: school and family education; interactions with the school; contingencies in schooling; personal and family achievements in schooling. The social context and the personal experiences of the research participants and their children with the school indicate the formation of three social representations. The schooling as: utility subordinated to family needs and projects linked to work; as a complement to the domestic educational process focused on moral aspects and parental care; and as correction and discipline for social interaction.

Keywords: Schooling; Working parents; Employment-schooling relationsh.

\section{Introdução}

A centralidade da escolarização é trazida nas discussões não só como condição para mudança social, democratização, cidadania e garantias futuras, mas também pelos desequilíbrios sociais a ela associados (MARTINS, 1972; RUMMERT; ALVES, 2010; NEVES, 2016). À baixa escolaridade associa-se estagnação e segregação; e, à sua elevação, distinção e mobilidade social. A escolaridade se constitui em uma variável explicativa, interdependente do trabalho, saúde, relações de gênero, seguridade social e pública, e na retroalimentação do desempenho escolar. A escolarização, por incrustar-se no cotidiano de distinções, contingências e vicissitudes dos trabalhadores, é um objeto social (OS) apreendido em função dos pertencimentos sociais e das ideologias associadas a ela (BUENO, 2001). 


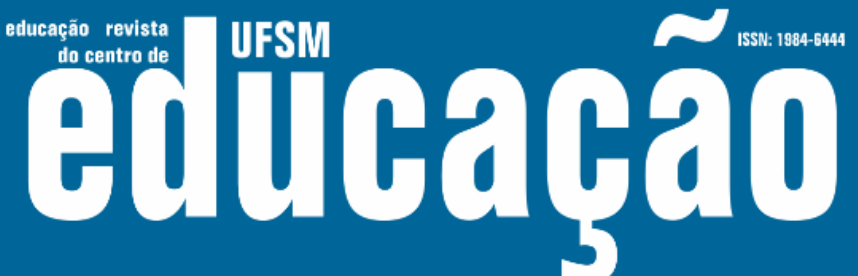

ISSN: 1984-6444 | http://dx.doi.org/10.5902/1984644432852

Ao trabalho e baixa escolaridade são estabelecidas associações como, entre outras, a oferta de emprego, empregabilidade e salário (BALASSIANO; SEABRA; LEMOS, 2005; RUMMERT; ALVES, 2010), desempenho laboral (ARANTES; BORGES, 2013), nível salarial (OLIVEIRA; IRIART, 2008), segurança (RAMOS, 2016), formalidade (GÓMEZ, 2017), salubridade, segurança laboral e contaminação (SOARES, 2017), trabalho escravo (BELTRAMELLI NETO; ADÃO, 2017) e trabalho infantil (MARTINEZ, 2001; SANTOS, 2002; DINIZ, ASSUNÇÃO et al., 2012). Nesse contexto, as demandas de escolarização associadas ao trabalho (GOMES; SANTOS, 2017) e ao trabalhador (OLIVEIRA; IRIART, 2008) são crescentes. A escolarização precária empurra os ingressantes no mercado de trabalho para o subemprego, a informalidade e ausência de direitos trabalhistas e previdenciários. Entre as consequências da informalidade estão os problemas que envolve a aposentadoria, sua comprovação por tempo e contribuição, restando-lhes a alternativa da aposentadoria por idade, de menor valor (CASTRO et al., 2015).

$\mathrm{Na}$ esfera da saúde a baixa escolaridade está associada à natalidade (SILVA; HASENBALG, 2000), higiene (FORTUNATO; VICENZI, 2014), alimentação (MOURA; MASQUIO, 2014), obesidade (MONTEIRO; CONDE; CASTRO, 2003; TENORIO; COBAYASHI, 2011; MOURA; MASQUIO, 2014), diagnóstico de doenças e adesão a tratamentos (ARAÚJO; SILVA, 2010), prevenção de doenças (MASSON; MONTEIRO, 2010), tabagismo (AFONSO, 2017) e alcoolismo (MELO, 2017), entre outros fatores.

A escolaridade dos pais é uma das variáveis macrossociais relacionada ao desenvolvimento do sujeito (CALEJON, 2011); à percepção do papel da família na escolarização dos filhos (MELO, 2017); à expectativa de desempenho e suporte ao estudo dos filhos (LOPES NETA, 2014); ao acompanhamento das rotinas escolares (SANTOS, 2002); ao enfrentamento das dificuldades de aprendizagem dos filhos (LOPES NETA, 2014); à regularidade dos percursos escolares (LEÃO; NONATO, 2012); e à evasão e ao baixo desempenho escolar (CHECHIA; ANDRADE, 2005). A baixa escolaridade e qualidade educacional dificulta o enfrentamento dos problemas de classe, raça e gênero. As relações de gênero incidem tanto subjetiva quanto socialmente (TUPPY; ARRUDA, 2005) em questões ligadas à sexualidade, orientação sexual e natalidade. A feminização da pobreza está associada ao analfabetismo e à 


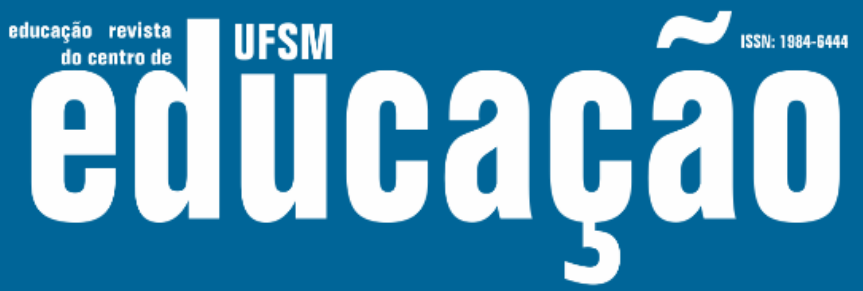

ISSN: 1984-6444 | http://dx.doi.org/10.5902/1984644432852

baixa escolaridade que levam à ausência de qualificação profissional e ao trabalho informal. Tais condições restringem a mulher ao espaço doméstico e cuidado dos filhos (MARIANO; CARLOTO, 2011). Além dessas associações, o trabalhador com baixa escolaridade pode enfrentar problemas de natureza racial, moradia e cidadania (SOUSA, 1995).

As pesquisas sobre a escolarização, na vida do trabalhador e seus filhos, abordam o problema em aportes teóricos macrossociológicos estruturais como reprodução social ou cultural, e, nos microssociológicos como resultante do jogo entre diversas lógicas sociais e familiares. Ante esse panorama, as representações sociais articulam, simultaneamente, pelas vinculações que estabelecem entre o psicológico e o social, em diferentes escalas, consensos e diferenciações, o social e o individual (DIOGO, 1998). Assim, os significados da escolarização para os trabalhadores/atores sociais, situados nesse contexto, apresentam-se para a gestão educacional e à docência como potencialidades e limites em qualquer forma de intervenção (JODELET, 2007).

Por diferentes razões, esses trabalhadores passaram, abandonaram, foram excluídos da escolarização e na escola por suas condições materiais e de funcionamento (FERRARO, 1999). Tais relações permitem inferir que a escolarização pode representar a inclusão ou a exclusão do mundo do trabalho e social; indicar qualidade de vida, bem-estar social, condições laborais e desempenho educacional; associar-se ao dinamismo social e produzir novas relações escolarização-trabalho; mudar e reproduzir esse trabalhador que é simultaneamente sujeito com experiências e conhecimentos produzidos sobre essa realidade; ser um objeto de representação social na confluência do meio social sobre o sujeito e nas construções do trabalhador sobre seu contexto.

Considerando a escola como agente ativo do sucesso e do fracasso da escolarização, e o trabalho como processos imbricados, a teoria das representações sociais pode expressar a compreensão de trabalhadores informais e desempregados sobre a escolarização. Assim, tem-se na escolarização o objeto social, crucial na definição do contexto do sujeito - trabalhador com diferentes níveis de escolaridade como parte do seu próprio projeto de vida, em suas contingências, com seus 


\section{F HEM

ISSN: 1984-6444 | http://dx.doi.org/10.5902/1984644432852

posicionamentos e memórias, respondendo a ele e construindo explicações enraizadas em seus contextos. Ante esse quadro objetiva-se analisar as representações sociais de trabalhadores informais e desempregados com diferentes escolarizações, pais de alunos da Educação Básica que frequentam o sistema público de ensino sobre a escolarização.

\section{Fundamentos teóricos}

As representações sociais integram conceitos e explicações sobre os objetos sociais como uma expressão dos conhecimentos construídos em condições históricosociais e da funcionalidade na instauração, ou na manutenção das práticas sociais (GUARESCHI, 1999). Essas representações remetem aos "sistemas complexos de significações elaboradas por grupos sociais", permitindo a compreensão da escolarização "em referência a um ambiente social mais amplo", para além da escola, permeado dos condicionantes históricos (GILLY, 2001, p. 331).

A teoria original (MOSCIVICl, 1961/2012) foi enriquecida e ampliada nas seguintes abordagens: a dimensional, da teoria Moscovici; a estrutural, da organização entre os elementos centrais e periféricos de Abric (2003); e a dinâmica, que traça as transformações de uma representação social de Jodelet $(2007,2015)$. A pesquisa desenvolvida segue a abordagem dimensional e dela explicitam-se os mecanismos formativos e as suas dimensões. Da formação das representações sociais destacam-se os mecanismos da ancoragem e da objetivação. As dimensões que integram uma representação social são conhecimentos ou informações, imagens e atitudes. Explicitam-se, inicialmente, os mecanismos formadores e suas dimensões.

Representar um objeto significa inscrevê-lo "em nosso universo [...] e dar-lhe contexto inteligível, ou seja, interpretá-lo" (MOSCOVICl, 2012, p. 60), e nesse processo atuam a ancoragem e a objetivação. A ancoragem transforma uma situação cotidiana subordinando-a, na comunicação, aos conhecimentos e às normas sociais "em rede de significações". Ancorar um objeto social significa inseri-lo nos "valores e nas operações concretizadas pela sociedade". Nela, um objeto social é instrumentalizado e posto em uma "escala de preferência nas relações sociais 


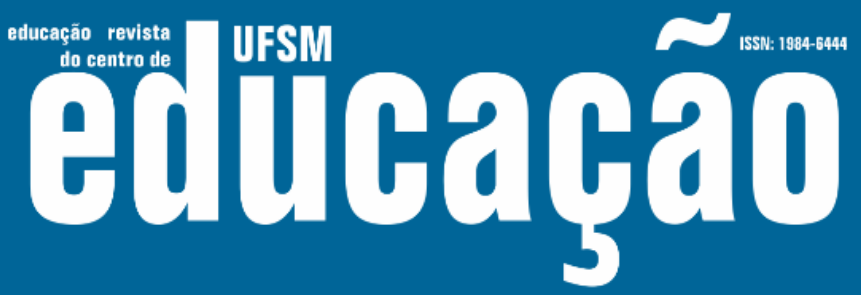

ISSN: 1984-6444 | http://dx.doi.org/10.5902/1984644432852

existentes" (MOSCOVICl, 2012, p. 156). Assim, ancorar a escolarização é enquadrála nos conhecimentos sociais existentes e circulantes sobre ela.

A objetivação trabalha na simplificação e materialização das informações para torná-las observáveis. Não por acaso, Moscovici a associa aos verbos contribuir, mostrar, permitir, remediar e transferir conceitos e sentidos. De acordo com o autor, a objetivação "contribui para edificar o núcleo imageante da [...] realidade social" (2012, p. 260); "permite tornar real um esquema conceitual e substituir uma imagem por sua contrapartida material" (2012, p. 60); "mostra como os elementos representados [...] se integram a uma determinada realidade social" (2012, p. 158). Em outras palavras, a objetivação traz o objeto ao "domínio do ser", e a ancoragem o delimita no domínio "do fazer para contornar o impedimento de comunicação" (2012, p. 156; grifos originais.).

A escolarização e sua teia de interações sociais, econômicas, educacionais e históricas, entre outras, assumem formatos diferentes para trabalhadores comparados a sociólogos, economistas, educadores e historiadores. Porém, as representações sociais em sua dinâmica consideram a ambos "criadores e comunicadores, utilizadores e selecionadores das informações". O conhecimento presente em uma representação social liga-se à experiência e sistemas "de valores, de noções e de práticas que dão aos indivíduos os meios necessários para se orientar no ambiente social e material" (MOSCOVICl, 2012, p. 28). Assim, o conhecimento sobre a escolarização presente na representação social desses trabalhadores subordina-se ao universo consensual e comunicacional de ordem prática, e não ao universo reificado da ciência.

As imagens utilizam os materiais existentes na natureza e conhecidos para traduzir e concretizar os pensamentos do cotidiano do grupo social. Elas destacam aspectos relevantes do objeto representado e se expressam nas comparações elaboradas para aproximar as explicações do universo cotidiano. Ao filtrarem as informações e direcionarem a interpretação dos conhecimentos e experiências, as imagens favorecem a convergência entre os conhecimentos interiores e os exteriores aos sujeitos. Comparando com a ciência, percorrem o caminho inverso, concretizando os conteúdos sem intermediações ou rodeios, mas pelos predicados dos lugares 


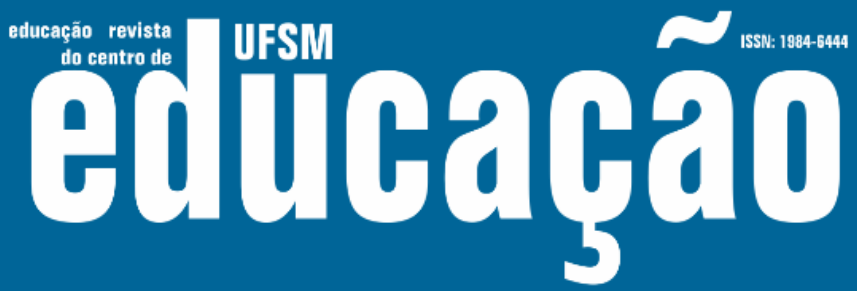

ISSN: 1984-6444 | http://dx.doi.org/10.5902/1984644432852

comuns em que se fala e se mostra (MOSCOVICI, 2012).

A função orientadora e normativa das representações sociais é expressa pela atitude dos sujeitos, em um contexto no qual representar um objeto significa assumir um posicionamento favorável, contrário ou indiferente frente a ele. Assim, as atitudes expressam: os posicionamentos em relação a um objeto, acontecimento ou experiências associadas às representações sociais; a predisposição para a ação, prevendo o que o sujeito vai fazer e dizer dentro do contexto social em que o objeto é aprendido; a orientação psíquica favorável ou desfavorável "revelada por um comportamento global ou por uma série de reações cuja significação é comum" (MOSCOVICI, 2012, p. 445).

As três dimensões das representações sociais sobre a escolarização em sua interface com o trabalho - conhecimento, imagens e atitudes - fornecem uma visão de conjunto do seu conteúdo e sentido. Os elementos dessa interface são convertidos em relação aos valores e imagens arraigadas na realidade social como um corpo natural de conhecimentos. Analisar a escolarização como representação social entre trabalhadores de baixa escolaridade, informais e/ou desempregados significa, portanto, buscar as formas da sua apropriação, transformação e tradução a partir da experiência vivida na escola, no mundo do trabalho e na luta pela sobrevivência.

A articulação do contexto social com o escolar fundamenta-se no princípio de que a realidade é simbolicamente construída/representada e as informações circulantes corroboram as construções dos sujeitos sobre os objetos sociais. Dessa forma, as práticas vividas, partilhadas e circulantes dos trabalhadores com baixa escolaridade, a partir da abordagem teórico-metodológica das representações sociais, possibilitam o acesso às traduções e comunicações que organizam o seu cotidiano e o de seus filhos em relação à escolarização (MOSCOVICI, 2003, 2012; JODELET, 2005, 2007).

Os trabalhadores podem apresentar a tendência de reproduzir nos filhos a sua baixa escolaridade (AQUINO; FERNANDES et al., 2010; NEVES, 2016) não só pelas contingências enfrentadas, mas também pelos significados atribuídos a ela (GILLY, 2001). Diante disso, pode-se afirmar que a escolarização se torna um objeto social relevante apreendido nas relações e espaços sociais, de forma própria e diferenciada dos docentes, sendo, ao mesmo tempo, estranho a eles. Assim os trabalhadores não 


\section{F HWM etituará

ISSN: 1984-6444 | http://dx.doi.org/10.5902/1984644432852

apenas reproduzem a lógica dada à educação pelo poder hegemônico do educar para instruir, para prevenir e para produzir (RUMMERT; ALVES, 2010), como também produzem significados próprios sobre a escolarização a partir das experiências vividas (JODELET, 2005).

\section{Coleta de informações e análises}

No artigo são analisadas as representações dos trabalhadores com baixa escolaridade, desempregados ou informais, e não a partir do ambiente escolar ou dos seus agentes. Trata-se de sujeitos em que a escolarização é parte do projeto e das contingências de vida.

Para atender essa situação foi necessária atenção especial às estratégias metodológicas. Segundo as informações da Síntese de Indicadores Sociais (SIS) 2010, a média de escolarização dos brasileiros com mais de 15 anos de idade era de 7,5 anos de estudo, e no Paraná essa média era de 7,8 anos para os homens e 7,9 para as mulheres. Isso indica que muitos brasileiros não conseguiam concluir o ciclo fundamental de escolarização obrigatória, um direito adquirido constitucionalmente (BRASIL, 2010). Para inclusão na pesquisa, além da escolaridade inferior a oito anos, constituíram-se como critérios: ser pai ou mãe de aluno da Educação Básica do sistema público de ensino; ser trabalhador da construção civil, trabalhador da agricultura, empregado no setor da higiene e limpeza entre outros; ser autônomo, possuir vínculo trabalhista instável ou de prestação de serviços temporários; ser beneficiário de Programas Sociais.

A partir dessa delimitação, com as dificuldades encontradas na coleta de informações esses critérios foram alargados, passando a incluir desempregados, alguns com escolaridade superior à estipulada, trabalhadores de barracões de reciclagem e participantes dos cursos de capacitação do CRAS (Centros de Referência de Assistência Social). As informações obtidas em condições diferentes das projetadas são processadas como variáveis de análise.

A pesquisa é de abordagem mista, englobando tanto métodos quantitativos quanto qualitativos. Os procedimentos quantitativos e qualitativos são tomados como 


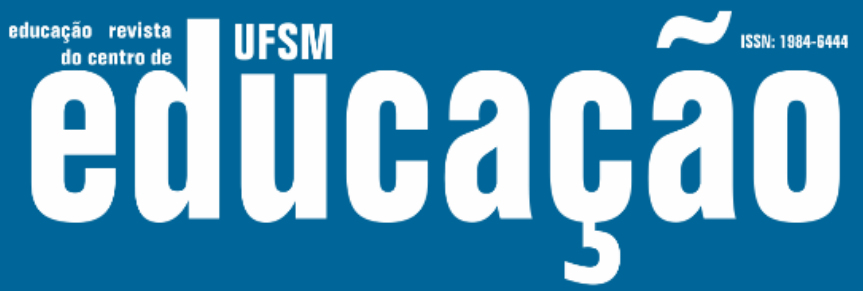

ISSN: 1984-6444 | http://dx.doi.org/10.5902/1984644432852

abordagens complementares e constitutivas uma da outra, perpassados pela interpretação qualitativa e hermenêutica (FERRARE, 2011). Como "o discurso espontâneo não é a representação social" (FLAMENT, 1994, p. 116), foram necessários procedimentos complementares na coleta e análise das informações para chegar às representações sociais dos trabalhadores.

Os problemas na coleta de informações com os trabalhadores de baixa escolaridade abarcam tanto a confecção dos instrumentos de coleta quanto os procedimentos de análise (BORGES; PINHEIRO, 2002; ANTIPOFF; FRADE; LIMA, 2016). Porém, ao se evitar a coleta de informações desse contingente populacional rompem-se os vínculos da aplicabilidade e da relevância social, os quais são cultivados pela educação crítica e libertadora não só com ações político-pedagógicas na unidade escolar, mas também como estratégias para a promoção de oportunidades no contexto socioeconômico. Levando-se em conta as dificuldades de se ter material autoaplicável ao público, a coleta de informações deu-se mediante questionário com questões abertas e fechadas, configurando-se como uma entrevista estruturada. $\mathrm{Na}$ elaboração do questionário, além das delimitações iniciais, considerou-se tanto o processamento de dados exploratórios de trabalhadores com escolarização inferior ao ensino médio, como os dados de pesquisa de Serpe (2015) e de Oliveira (2016), cada uma delas com informações de 60 pais de crianças e adolescentes atendidos no Contraturno Social.

O perfil sócio demográfico dos informantes está expresso na Tabela 1. Nela os sujeitos são descritos a partir das seguintes variáveis censitárias: sexo, faixa etária, locais de coleta de informações, estado civil, filhos matriculados na educação básica, escolarização, relato de trabalho infantil, recebimento de benefício social e gravidez na adolescência. 


\section{U Futbap̧a}

ISSN: 1984-6444 | http://dx.doi.org/10.5902/1984644432852

Tabela 1: Variáveis censitárias dos informantes

\begin{tabular}{|c|c|c|c|}
\hline & Variáveis & Freq. & $\%$ \\
\hline \multirow{2}{*}{ Sexo } & Masculino & 36 & 24,8 \\
\hline & Feminino & 109 & 75,2 \\
\hline \multirow{4}{*}{ Faixa etária } & Até 30 anos & 27 & 18,6 \\
\hline & De 31 a 40 anos & 40 & 27,6 \\
\hline & De 41 a 50 anos & 52 & 35,9 \\
\hline & Mais de 51 anos & 26 & 17,9 \\
\hline \multirow{3}{*}{$\begin{array}{l}\text { Locais de coleta de } \\
\text { informações }\end{array}$} & Agência do Trabalhador & 75 & 51,7 \\
\hline & Barracões de reciclagem & 15 & 10,3 \\
\hline & SOS & 55 & 38,0 \\
\hline \multirow{2}{*}{ Estado civil } & Solteiro ou equivalente & 58 & 40,0 \\
\hline & Casado ou equivalente & 87 & 60,0 \\
\hline \multirow{2}{*}{ Filhos na Educação Básica } & Possui filhos na escola & 107 & 73,8 \\
\hline & Não possui filhos na escola & 38 & 26,2 \\
\hline \multirow{2}{*}{ Escolarização } & Até nove anos & 65 & 44,8 \\
\hline & Superior a nove anos & 80 & 55,2 \\
\hline \multirow{2}{*}{ Trabalho Infantil } & Histórico de trabalho infantil & 39 & 26,9 \\
\hline & Sem histórico de trabalho infantil & 106 & 73,1 \\
\hline \multirow{2}{*}{$\begin{array}{l}\text { Recebimento de benefício } \\
\text { social }\end{array}$} & Recebe benefício social & 59 & 40,7 \\
\hline & Não recebe benefício social & 86 & 59,3 \\
\hline \multirow{2}{*}{ Gravidez na Adolescência } & Relata gravidez na adolescência & 25 & 22,9 \\
\hline & Não relata gravidez na adolescência & 84 & 77,10 \\
\hline
\end{tabular}

Fonte: Autores

Completando as informações que constam da Tabela 1, a variável Escolarização, em função da média nacional comporta três subgrupos de informantes para cada grupo. No primeiro grupo participaram 6 analfabetos, $16 \mathrm{com}$ ensino fundamental incompleto e 43 com ensino fundamental completo, totalizando 65 sujeitos entrevistados. No segundo grupo participaram 11 sujeitos com o Ensino Médio Incompleto, 57 com Ensino Médio Completo ou Superior Incompleto e 12 sujeitos com Ensino Superior em Administração, Ciências Contábeis e Pedagogia. Assim, além da escolaridade a situação de desempregados ou de informalidade delimita o perfil dos participantes.

Das 145 entrevistas efetuou-se o recorte das produções discursivas que versavam sobre a história pessoal de escolarização; à escola em geral e às escolas em que seus filhos estudam, em particular; e às comparações feitas sobre essas escolas. Após o 


\section{$\sim$

ISSN: 1984-6444 | http://dx.doi.org/10.5902/1984644432852

recorte das informações preparou-se o corpus para analisá-lo no Alceste e Nvivo. Para a análise no Alceste cada produção discursiva foi identificada com uma linha de comando em que constavam as informações sobre os entrevistados. Do Alceste utilizaram-se os relatórios da análise lexical que informam as classes discursivas e as variáveis censitárias associadas a elas. Esse procedimento permite analisar as diferenças argumentativas e a origem delas associadas aos subgrupos traduzidos pelas variáveis de identificação. Para traduzir as informações circulantes apresenta-se a classificação hierárquica descendente e fragmentos dos textos que contribuíram para a sua contextualização. O programa Nvivo promoveu a análise de sentimentos, a qual, para os objetos sociais em análise, permite apreender as atitudes dos informantes sobre eles.

As classes obtidas na análise estão apresentadas na Figura 1. Para organização e apresentação do dendrograma, adotou-se como critério de corte o quiquadrado superior a 7,68 e a frequência mínima de seis palavras analisadas, critérios duas vezes superiores aos padrões mínimos. 


\section{WFM \\ $\sim$

ISSN: 1984-6444 | http://dx.doi.org/10.5902/1984644432852

Figura 1: Classificação Hierárquica Descende da análise lexicográfica executada pelo software Alceste.

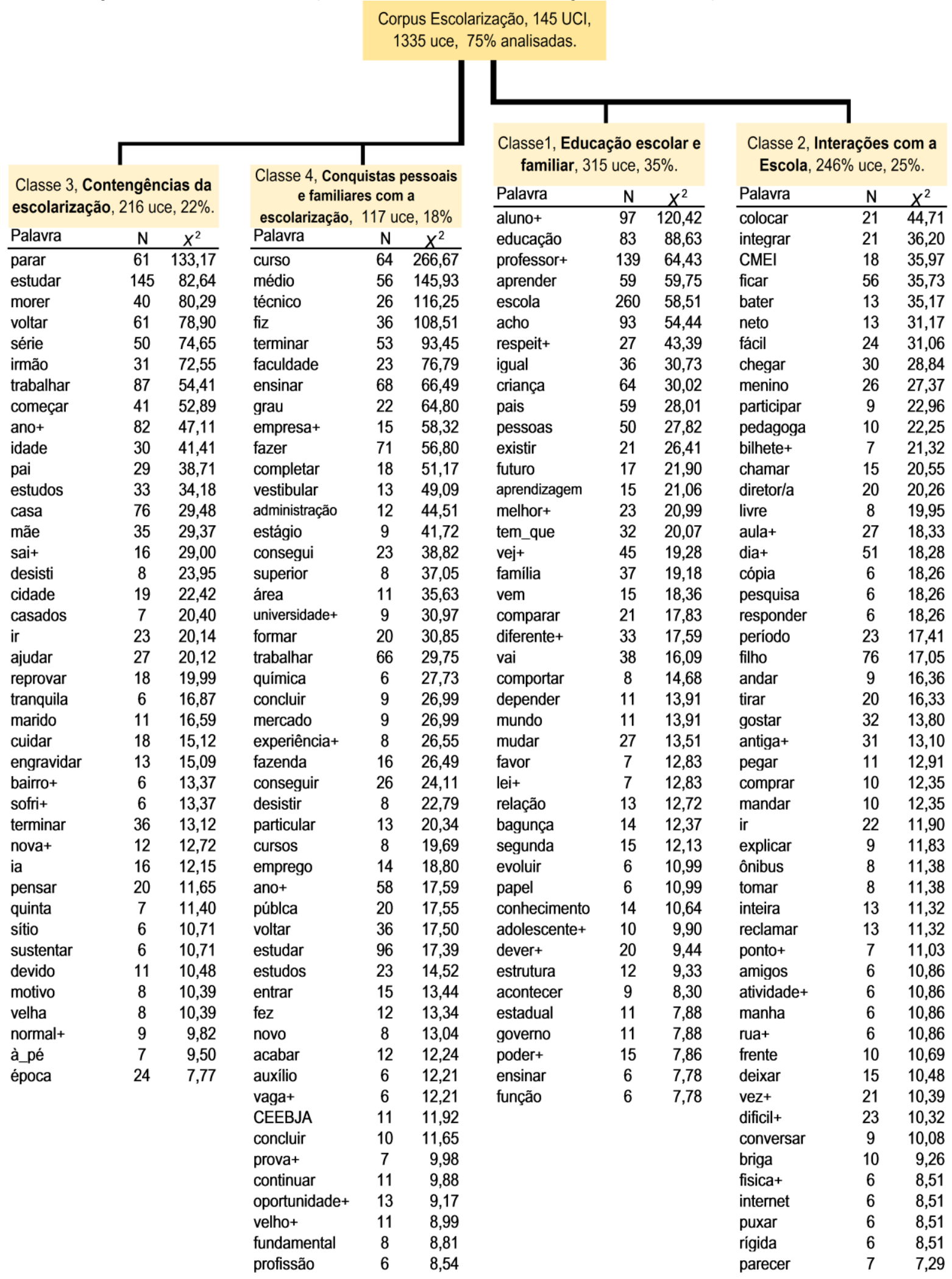

Fonte: Autores. 


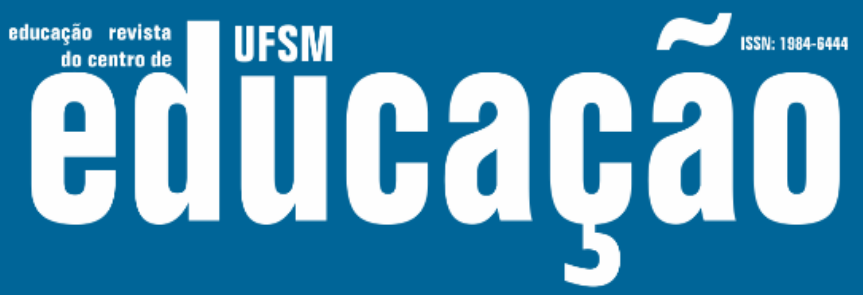

ISSN: 1984-6444 | http://dx.doi.org/10.5902/1984644432852

As variáveis que tiveram importância estatística sobre os informantes que contribuíram na constituição da classe 1, em ordem decrescente, foram: o local de coleta de informações no SOS; filhos frequentando a Educação Básica; escolarização superior à média nacional de 7,5 anos de estudos; e estado civil de casados ou equivalente. As variáveis que entraram na constituição da classe, mas sem importância estatística, foram: beneficiários de programas sociais; terem de 31 a 40 anos de idade; e pertencerem ao gênero masculino. A classe apresenta as atribuições da família e da escola na educação em seu sentido lato, e da escolarização em sentido estrito.

Os sujeitos a quem os informantes se referem são os atores do processo educacional, como alunos, crianças e adolescentes; os educadores professores e pais ou família; e outros atores nominados genericamente como pessoas, igrejas e o governo como gestor da escola pública e políticas educacionais. Os objetos da classe são as atribuições das instituições, dos agentes e espaços educativos, e as relações entre eles. As atribuições são expressas nos termos papel, função, lugar da escola. As relações desejadas são as expressas em diálogo, igualdade, complemento, amor, prazer, futuro, em oposição aos denunciados como diferença, violência e bagunça. A educação associa-se à escola, sala de aula, aprendizagem e conhecimento. Dessas relações integram-se escola, família, sociedade e governo. Sobressaem, também, metas normativas como obrigação, esforço, rigor e lei. As ações associadas à classe expressam os desejos de mudanças entre os atores educacionais.

A avaliação da educação está nos verbos achar (acho), ver (vejo, vemos, vê, vendo), vir (viria e vem) ser, estar e existir (seja, fosse, estiver, tivesse, existisse), melhorar, acreditar, evoluir, mudar e investir. As afirmações estão associadas aos verbos de cunho imperativo ou dever (tem que, deve, deveria). Quanto à relação pedagógica, observam-se os verbos ensinar, aprender, conviver, valorizar, crescer e respeitar. A comparação da educação e do espaço escolar com a família ou igreja é expressa por meio das palavras importante, futuro, igual e, também, diferente. Um dos anseios dos pais em relação à educação é o de que seus filhos procedam, de fato, como crianças/adolescentes educados, e não como rebeldes sujos e perdidos que fazem coisas erradas. 


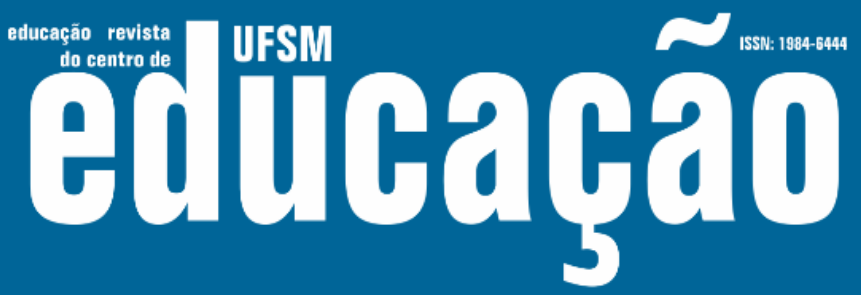

ISSN: 1984-6444 | http://dx.doi.org/10.5902/1984644432852

A relação entre passado e futuro traz à cena a ideia de qualidade, que se perde com o passar do tempo: "A escola era melhor, porque não tinha bagunça dos adolescentes, os professores eram mais focados". Com essa lógica, a expectativa de futuro é de "pessoas ignorantes, com conhecimento, mas ignorantes [...] não tem futuro para os jovens". Essa ideia perpassa também a avaliação da família, porque "o pai não tem controle".

Os informantes fazem uma distinção entre educação e ensino, ao afirmarem: "A escola não é lugar de dar educação, e sim para dar aprendizado, e enfrentar o mundo, quanto mais conhecimento, a pessoa sabe lidar com as situações, no dia a dia". Educação o aluno precisa "aprender dentro de casa", e a escola "é o lugar onde deve haver o prazer sobre o saber, aprender". Com essa demarcação a casa é o lugar da educação, e a escola é "um lugar que a pessoa vai para aprender, é como se fosse um trabalho, porque a pessoa convive com outras pessoas, aprende a se comportar e conviver". A educação é defendida no plano dos valores, "do caráter [...] do respeito (e de como) a criança vai se comportar lá fora". O ideal educacional envolve o aspecto normativo e corretivo de "segurar", "controlar", "saber conviver". Apesar de compreenderem que família e escola possuem diferentes atribuições, o centro está na família e a escola é "um complemento", "continuação da educação que é dada em casa", pois as crianças "vão para a escola para aprender, português, matemática, não para serem educados". Destaca-se ainda a esperança na escola, pois os professores "se empenham bastante, fazem um esforço, para educarem os alunos", e a escola é "uma das coisas mais importantes de nossas vidas".

A classe 2 compara as dificuldades de natureza pessoal, dos materiais escolares, deslocamentos e acompanhamento da escolarização. As variáveis com importância estatística para a constituição da classe, em ordem decrescente, foram: ter passado por gravidez na adolescência e possuir escolarização até à média nacional de 7,5 anos de estudos; e as variáveis sem importância estatística foram: gênero feminino, estado civil de solteiro ou equivalente. Já as faixas etárias dos informantes foram duas: idade superior a 51 anos e idade de 31 a 40 anos. Essa classe apresenta participação e interações da família na vida escolar para a educação dos seus filhos; relata conflitos pessoais e do acompanhamento de filhos e netos, e 


\section{Autตaดูão}

ISSN: 1984-6444 | http://dx.doi.org/10.5902/1984644432852

as preocupações de segurança, controle, correção e ordem.

A classe refere-se aos sujeitos neto/a, menino/a, filho/a, piá e criança, e eles são considerados não por serem alunos, mas pelos seus laços familiares; os atores escolares são instituídos como professora, pedagoga e diretor, o que indica interações entre a família e a escola, e o acompanhamento do Conselho Tutelar. A escola é descrita como CMEI e creche em seus espaços de salas de aula, possuindo quadra para jogos, brincadeiras e atividades. Os deslocamentos dos alunos (rua, vila, ônibus, cartão, ponto), seus materiais escolares (caderno, régua, livro) e vestimenta (calça, tênis, roupa, boné) preocupam os pais informantes, sobretudo pelo custo de todas essas coisas e pela dificuldade de tê-las. Das interações são nomeados atenção, tratamento, amizade, bulliyng, bilhete, palestra, palavra e internet. É trazida à cena a gravidez na adolescência como interrupção da escolarização. As ações associadas ao espaço escolar são as típicas da Educação Infantil: participar, frequentar, gostar, adorar, brincar, cantar, jogar, correr; as de atenção, como chamar, conversar, falar, mandar, explicar, marcar, perguntar, reclamar, questionar, perceber e olhar; de desconforto e conflito, como brigar, bater, puxar, tomar, responder, chorar e deixar; e de deslocamentos, como ir (iria, iam, íamos), andar, chegar, ficar e esperar. As ações escolares típicas dos alunos são copiar, pesquisar, ler, acessar e passar. As qualificações que descrevem a escola são integral (modalidade), fácil e ótima, na forma de controle rígida, na comparação temporal de antigamente. A comparação temporal destaca a importância do maior acesso e apoio institucional para a permanência dos alunos no espaço escolar.

Sobressaem na classe os conflitos educativos e críticas às discriminações e "injustiças" da escola com as famílias e educandos. Volta à cena o saudosismo da escola do passado, que, mesmo não tendo atividades, ficava aberta e acolhia os alunos para brincarem e jogarem, ao contrário da escola do presente, em que no contraturno a criança fica "numa sala sem fazer nada, assistindo televisão", sem controle. Sobre a importância do controle, os informantes criticam o Estatuto da Criança e do Adolescente por passar "muita mão na cabeça [...] e não ajudar em nada", ao contrário do seu tempo, em que o professor ou diretor "chegavam na sala, todos tinham que ficar de pé. Para entrar na sala de aula, tinha que fazer fila, [...] 


\section{Fusm Ellloahă}

ISSN: 1984-6444 | http://dx.doi.org/10.5902/1984644432852

cantar o hino nacional, todos quietos". Apesar do reparo, alguns informantes reconhecem os CMEI como espaço aberto e acolhedor, "a escola perfeita"; afirmam que algumas situações mudaram nesses locais com o acesso à informação e a participação da família.

$\mathrm{Na}$ classe 3 as variáveis com importância estatística são, em ordem decrescente, a escolarização dos participantes até o Ensino Fundamental completo e o fato de atuarem nos barracões de reciclagem, relatarem trabalho infantil e terem entre 41 até 50 anos de idade. A variável que também entra na constituição da classe, mas sem importância estatística, é o gênero feminino. A classe destaca as lutas e fracassos no enfrentamento das contingências de ordem familiar e do sistema escolar.

Os sujeitos da classe são entes do universo familiar: pai, mãe, avô, irmão/ã, marido, mulher, os quais relatam a história de escolarização a partir das contingências do universo familiar. Os objetos que constituem a classe são de natureza espacial: cidade, centro, bairro, sítio; do percurso escolar: série, ano, quinta, sexta, primário, supletivo e estudos; do universo do trabalho: salário, serviço, supermercado e doméstica; e das contingências familiares: condições, necessidade e motivo. As ações associadas a esses sujeitos e situações são relativas ao estudo: parar, desistir, abandonar, reprovar, perder, estudar e sair; às razões do abandono: ajudar, cuidar, sair, ficar, sustentar, dificultar, sofrer, morrer e falecer; e à oposição: trabalhar, arrumar, procurar e começar. Se as ações relativas aos estudos indicam interrupção, elas também acenam para a retomada em: pretender, voltar, prosseguir, terminar, concluir. A ação frente à história apresentada é a de arrepender-se. As qualificações frente à escola são: tranquila, normal e ótima; e as relacionadas aos professores e às contingências aparecem como: desempregada, doente, velha e sozinha. Sobre o percurso da escola, a forma indicada é esta: a pé.

As contingências pessoais e a pobreza familiar, associadas aos limites do sistema escolar, são as que retiram as crianças e adolescentes da escola e os empurram para o mercado informal de trabalho. As maiores contingências referem-se aos problemas familiares de alcoolismo, doença, falecimento de um dos genitores, gravidez na adolescência e cuidado de irmãos menores para as mães trabalharem, mas a principal delas aparece nas entrelinhas da "necessidade de trabalhar", como 


\section{Eutha \\ 1SSN: $1984-6444$

ISSN: 1984-6444 | http://dx.doi.org/10.5902/1984644432852

sinônimo de pobreza. Do sistema escolar destacam-se a infraestrutura, a oferta limitada dos anos de estudo e a ausência de transporte escolar. Não é por acaso que como uma das variáveis de peso na constituição da classe está o trabalho infantil. 0 enredo torna-se repetido, com pequenas variações: contingências familiares ou escolares; abandono da escola; mercado de trabalho informal; tentativas de recomeço da escolarização; e arrependimento.

A classe 4 tem como variáveis com importância estatística, em ordem decrescente, a escolarização superior ao Ensino Fundamental completo; os participantes aparecem na Agência do Trabalhador como desempregados, mas em busca por emprego; não se constata em suas entrevistas o relato de trabalho infantil; não recebem qualquer benefício social; são do gênero masculino e as variáveis que também entram na constituição da classe, mas sem importância estatística, é o estado civil de solteiros ou equivalente, com idade de 31 até 40 anos. Essa classe retrata os esforços e os caminhos trilhados para as conquistas pessoais e familiares na escolarização.

O sujeito em destaque na classe 4 é "eu", primeira pessoa do singular. Os objetos a que se refere são do universo de ensino além do ensino fundamental, ou de alternativas profissionalizantes. Estudos, curso, ensino médio e técnico ou segundo grau, supletivo, SENAI, CEEBJA, vestibular, faculdade, universidade, pós (graduação), diploma, áreas de conhecimentos - administração de empresas, ciências contábeis, economia, mecânica, engenharia, química, enfermagem, magistério, geografia, matemática, veterinária - retratam as preocupações e a escolaridade dos informantes. Interfaces com o mercado de trabalho aparecem nos substantivos concurso, profissão, escolha, mercado, cursos, lucro, vaga, prova, bolsa, estágio, currículo, experiência, oportunidade, emprego e indústria. As ações relatadas indicam realizações: fazer (faz+, fiz, fez), terminar, acabar, concluir, conseguir e formar; recomeço: voltar, estudar, querer (quiser), retornar, gostaria, tentar e continuar; ou abandono: trancar, demorar e desistir. Os adjetivos que sobressaem na classe são relativos à qualidade presente no debate sobre os sistemas particular e público de ensino. 


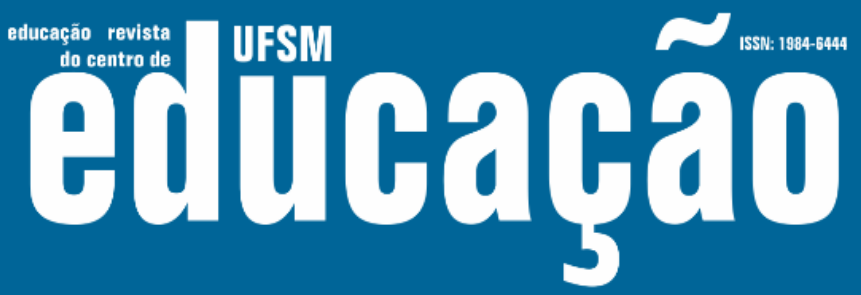

ISSN: 1984-6444 | http://dx.doi.org/10.5902/1984644432852

Tais dados dizem respeito tanto às conquistas pessoais quanto de familiares ou de parentes próximos que contrastam com as informações da classe anterior. Não se trata mais de trabalhadores à margem do mercado de trabalho, mas de trabalhadores que buscam recolocação. Com relação à escolarização, encontram-se avanços devido à persistência e aos caminhos alternativos proporcionados pelo supletivo, CEEBJA e SENAI. A relação escolarização emprego apresenta-se como nos casos citados a seguir: "Fiz um curso técnico [...] acabei engravidando e não dei continuidade aos estudos [...] hoje eu tenho dificuldade de entrar do mercado de trabalho, por falta do estudo; "Gostaria de ter estudado mais [...] estou tentando conseguir mais um grau de escolaridade no currículo; não dá para desistir".

É importante ressaltar que o projeto inicial de analisar as representações sociais de trabalhadores com baixa escolaridade, pais de alunos da Educação Básica que frequentam o sistema público de ensino, sofreu alterações em função das dificuldades na coleta de informações. Conforme a tabela 1, os informantes dentro desse critério correspondem a 44,8\%, mas as suas produções discursivas obtidas a partir da análise parametrada no Alceste correspondem a 41,50 \% das informações. Associados a eles estão as variáveis: local da coleta de informações nos barracões de reciclagem $\left(X^{2}=124,13\right)$; relato de trabalho infantil $\left(X^{2}=67,86\right)$; faixa etária com mais de 51 anos ( $\left.X^{2}=27,25\right)$; gravidez na adolescência $\left(X^{2}=24,44\right)$; estado civil solteiro ou equivalente $\left(X^{2}=20,83\right)$; e sexo feminino $\left(X^{2}=17,15\right)$. Na análise padrão a escolaridade abaixo do ensino fundamental completo contribuiu na constituição das classes 2 e 3 - Interações com a escola e Contingências da escolarização, com $X^{2}$ 5,81 e 59,78, respectivamente, em oposição às classes 1 e 4 - Educação escolar e familiar e Conquistas pessoais e familiares na escolarização, com $X^{2} 15,29$ e 38,07, respectivamente.

As diferenças e as contribuições discursivas desses grupos foram demarcadas na constituição das classes e, embora as classes 1-2 e 3-4 estejam pareadas em relação às interações com a escola e aos resultados com a passagem pela escola, elas se diferenciam e demarcam diferentes significados ante as conquistas e contingências. A classe 2 manifesta 0 apoio buscado na escola aos processos domésticos, enquanto a classe 3 indica os fracassos e tentativas de recuperar o 


\section{Fism Eutbapga}

ISSN: 1984-6444 | http://dx.doi.org/10.5902/1984644432852

percurso escolar. A classe 1 transita entre as atribuições da família, da escola, da educação e da instrução; já na classe 4 aparecem os percursos e conquistas pessoais e familiares obtidos com a escolarização.

Para a análise das atitudes as informações foram processadas no Nvivo. Cada um dos objetos sociais mencionados nas entrevistas se constituem em nós analisados no programa pelos termos associados a eles. A síntese da análise de cluster encontrase abaixo, na Figura 2.

Figura 2: Avaliação de sentimentos

\begin{tabular}{|c|c|c|c|c|c|c|}
\hline \multicolumn{3}{|c|}{ Positividade - - } & \multirow{2}{*}{$\begin{array}{c}\text { Neutralidade } \\
\text { Universidad } \\
\text { e Faculdade } \\
\text { Escola } \\
\text { Ensino } \\
\text { Estudo } \\
\text { Trabalho }\end{array}$} & \multicolumn{3}{|c|}{ 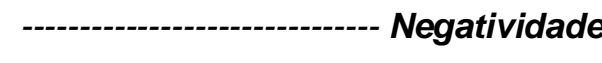 } \\
\hline Creche & Emprego & CMEI & & CEEBJA & Educação & Colégio \\
\hline
\end{tabular}

Fonte: Autores

Muito positivo, moderadamente positivo, positivo, neutro, negativo, moderadamente negativo e muito negativo são os sentimentos codificados pelo programa Nvivo. As informações presentes na figura 2 sugerem que quanto maior forem os cuidados necessários dispensados e ofertados aos seus filhos e à segurança familiar, maior é a aprovação dos genitores. No extremo oposto estão os objetos sociais que mediaram ou dificultaram os seus processos de escolarização. Essas atitudes indicam que esses objetos das experiências pessoais possuem um caráter neutro ou negativo, porém quando assumem as características de segurança e apoio parentais são positivos; a educação e os processos de escolarização são neutros ou negativos. Nessa atitude se apoiam as afirmações relativas à educação versus instrução polarizada em favor da família. Para além das críticas, a educação é boa se estiver subordinada às necessidades familiares e se a instrução garantir o acesso ao conhecimento, ao desempenho e à segurança, aos ganhos futuros com o trabalho e o emprego. Esses posicionamentos sugerem a utilidade dos objetos sociais e o lugar em seu presente e passado, contrariando a perspectiva do vir a ser educacional. 


\section{Fusm Eulloahá}

ISSN: 1984-6444 | http://dx.doi.org/10.5902/1984644432852

As imagens sobre a escolarização foram obtidas pela identificação, pelo agrupamento das falas relativas à educação e à escola ao emitirem comparações. Dessa análise sobressaiu a imagem de casa, segunda casa, extensão da casa, pelo tempo de permanência, cuidados dispensados, atenção, carinho, segurança e aconchego; e, também, pela correção. O de segunda casa estaria, também, no sentido de que, em primeiro lugar, estaria a família, e a escola e a educação apoiariam e completariam a tarefa familiar. Vejamos exemplos: "A escola é igual a minha casa [...] a professora tem um carinho com os alunos, está ajudando" (S38); "Eles se sentem bem, quando tem jogos e brincadeiras [...] gostam de participar" (S46); "Tem regras, educação. Os professores, estão ali com carinho, para ensinar as crianças, tem educação para evoluir na vida" (S108); como devem "respeitar a própria casa, tem que respeitar a escola também [...] em qualquer lugar do mundo tem que existir uma escola, sem escola não tem aprendizado" (S141).

Se a comparação casa-escola destaca espaços educativos, as imagens de família-escola destacam seus atores e as interações educativas. Eis algumas imagens: "Uma família grande, os professores, cuidam das crianças, estão sempre juntos" (S81); "A família começa a educação [...] para saber se comportar e a escola, seria (sua) continuação" (S119); "Na minha adolescência, todos os meus problemas familiares, que não conseguia resolver, eu contava com a escola" (S5). Como comentado anteriormente, reaparecem as especificidades, porque "os professores educam de um jeito, e a família de outro. A escola ensina as matérias, os conteúdos, e a família ensina uma educação diferente, respeito" (S76). No mesmo sentido estão as imagens que recorrem a entes familiares, destacando a mãe, que "precisa ao mesmo tempo ensinar e educar. Educar no sentido [...] (do) que é certo e errado" (S82); o padrinho, que "vai dar o apoio e ajudar" (S136); "acolher a pessoa, da maneira que a pessoa está indo [...] não pode ter julgamento, não pode ter normas que denigrem a pessoa por dentro" (S36); o fato de que "a família vem a ser o berço, mas a escola integra. Acho que o professor deve apresentar o conhecimento ao aluno, e deve ser muito cordial, gentil, porque o aluno vai se espelhar no professor" (S3). Nesse aspecto juntam-se também imagens do sagrado e do bem, associando igreja e religião à escola e à educação: “... porque ensina coisas boas” é o lugar em "que vão aprender 


\section{Fusm Ellubarâ}

ISSN: 1984-6444 | http://dx.doi.org/10.5902/1984644432852

muito" (S69); “... é muito importante" (S135); "ela dá educação, faz a parte dela, como as igrejas fazem a parte delas também" (S8).

Entre as imagens foram encontradas as do mundo laboral, como empresa, emprego e trabalho. Nesse mundo o aluno "... é apenas mais um, que faz parte de um sistema, tem um padrão, uma meta [...], mas não dá para representar como uma família" (S112); “Um emprego, precisa começar no início, e estudar” (S13); "A escola é um lugar que a pessoa vai para aprender como se fosse um trabalho, porque a pessoa convive com outras pessoas, aprende a se comportar, saber conviver com outras pessoas" (S51); "A escola é igual ao trabalho. Se a pessoa tem estudo, ela consegue trabalho", mas sem estudo até "consegue trabalho, mas é difícil, ganha pouco, é muito explorado" (S53); “... é igual ao trabalho, pois ela é muito importante. Nós fazemos de tudo para não perder, levar a sério o serviço". Na escola "tem que levar a sério, para progredir" (S80), "tem uma obrigação" (S84). Para finalizar, apresenta-se uma imagem/comparação que sintetiza essa relação em que a escola seria um trabalho "no sentido que precisa de responsabilidade, força de vontade, determinação. [...] Se não se adaptar na escola, dificilmente se adaptará no trabalho" (S106). Ao associarem a escolarização ao trabalho, essas imagens destacam o sentido de projeto, metas, disciplina e obrigatoriedade.

Enfatizam, também, o sentido de mediação, potencialização, formação e futuro. A escola é "igual ao curso preparatório para o futuro [...] para não sofrerem" (S90); "Quanto mais estudo, educação, mais oportunidade a pessoa terá. A escola é igual a oportunidade de ter uma vida boa" (S44). Ainda, “... é uma preparação, para nos tornamos pessoas melhores, para aprender e compartilhar o que sabemos. A escola é uma das coisas mais importantes de nossas vidas. A educação vem de casa. A escola é uma preparação para a vida" (S104). Com a escola, "a pessoa consegue aprender para aplicar na prática” (S21). Mais: "...crescer em estudo, sabedoria, comportamento, educação. A escola é a raiz de tudo" (S118); "A escola é fundamental" (S50); "... vem em primeiro lugar" (S142). Sem escola, "a pessoa não sabe ler uma bula de remédio" (S111); "... continua na mesma” (S55). Finalizando: "Para serem alguém, as pessoas têm que estudar [...] em primeiro lugar Deus e em segundo lugar a escola" (S143). 


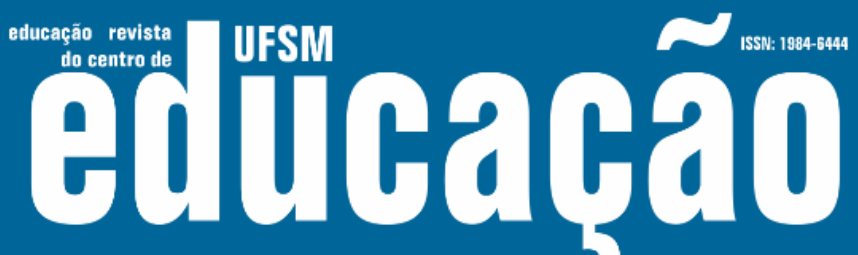

ISSN: 1984-6444 | http://dx.doi.org/10.5902/1984644432852

\section{Considerações finais}

Mediadas pela subjetividade e pela cultura produzida sobre a escolarização, as representações sociais dos trabalhadores com baixa escolaridade constituem-se dialeticamente nas interações com esse objeto social. A escolarização não é somente um dado episocial ou da reprodução ideológica, mas fruto das interações que se estabelecem no espaço escolar com o familiar e o social (MOSCOVICI, 2012). Assim, questionam-se as determinações apriorísticas de natureza eugênicas, sanitaristas e de privação cultural (PATTO, 1992), e destaca-se o processo ativo e complexo dos sujeitos negociando, reconstruindo e partilhando significados sobre esse objeto social. A captura dessas representações sociais é obtida mediante os percursos teóricos e metodológicos no entrecruzamento das dimensões - atitudes, imagens e informações - e dos seus mecanismos - ancoragem e objetivação.

A análise das atitudes expressa: aceitação da escola no apoio ao enfrentamento das dificuldades advindas da pobreza, baixa escolaridade e vulnerabilidade social nas falas sobre as creches e os CMEls; neutralidade ou ambivalência diante dos processos e agentes de escolarização; e crítica ao processo de escolarização que resulta das histórias pessoais e suas contingências. Os trabalhadores entrevistados aprovam o "alargamento das funções escolares" com a oferta de alternativas extraescolares que normalmente não alcançariam (QUARESMA; LOPES, 2011, p. 155). Tais atitudes estão associadas "às práticas cotidianas dos sujeitos, que legitimam as ações de aceitação/rejeição da própria instituição escolar" (OLIVEIRA et al., 2004, p. 31). Esses posicionamentos sugerem diferentes avaliações sobre a utilidade desses objetos sociais e sua temporalidade, contrariando a perspectiva de futuro que define as funções criadoras da educação e da escola (MARTINS, 1972; OLIVEIRA; VIANA et al., 2013) em favor das demandas do presente.

Corroboram essas atitudes as imagens trazidas sobre educação, escola e professores ao serem associadas à casa e à família, e as trazidas sobre o processo educativo, como trabalho e emprego. São imagens e comparações que põem o espaço doméstico e o familiar no centro do processo educativo, em favor da família e 


\section{Fusm Eutloará

ISSN: 1984-6444 | http://dx.doi.org/10.5902/1984644432852

suas necessidades. Essas imagens de escola, sob a lógica doméstica, subordinam o espaço-tempo da socialização compensatória à socialização primária de base familiar (QUARESMA; LOPES, 2011). Nesse arranjo, o acesso ao conhecimento, obtido pela instrução, é a garantia do desempenho e da segurança, dos ganhos futuros com o trabalho e o emprego. As imagens associadas aos aspectos de formação e mediação da escolarização se alinham às necessidades e demandas de ordem prática.

As informações presentes nas quatro classes referem-se aos atores, espaços, processos, ações e potencialidades atravessadas pela temporalidade, detalhando as vias delimitadas pelas atitudes e imagens associadas ao percurso escolar. Dos espaços sobressaem o doméstico, o escolar e o social; os tempos enfatizados são do passado (LIMA; COLUS et al., 2008) e do presente, sobre a história pessoal e lutas com seus filhos, e no futuro estão suas aspirações e expectativas; os atores são os do universo familiar, escolar e social; e as apreciações são simultaneamente de aprovação e crítica. Da educação escolar e familiar são destacadas as interações com a escola, as contingências e conquistas pessoais e de familiares com a escolarização. O enredo dos relatos transita entre as lutas cotidianas para frequentar a escola e nela manter-se, a interrupção da escolarização, as tentativas de retorno, os enfrentamentos para defender os filhos e netos, e vai até as conquistas pessoais e de familiares. As informações afirmam a ideia de que a educação vem de casa, e a escola complementa e garante o acesso ao bem-estar pessoal e social.

Complementam a análise os mecanismos que constituem as representações sociais ancoragem e objetivação. As justificativas aos fracassos, interrupções e abandonos da escolarização são ancoradas nas contingências ou privações de natureza pessoal, familiar ou institucional; e as escolhas feitas, nas justificativas de ordem prática e na sua utilidade. A função mediadora da escola e das esferas educativas - família e escola - são objetivadas nas comparações com a casa e a família. Os aspectos aprovados ou reclamados da escola são de ordem relacional e interpessoal de proximidade e acolhimento.

Assim é possível determinar três representações sociais.

1. Utilidade, em que a educação, para além das críticas, é boa se estiver subordinada às necessidades familiares e se a instrução garantir o 


\section{Wrm

ISSN: 1984-6444 | http://dx.doi.org/10.5902/1984644432852

acesso ao conhecimento, ao desempenho e à segurança, aos ganhos futuros com o trabalho e o emprego (NAIFF; SÁ; NAIFF, 2008; LOPES NETA, 2014; OLIVEIRA; SERPE; ROSSO, 2017). Nesse sentido, a escola assume caráter credencialista como proteção, sociabilidade, passaporte de futuro e liberdade para as crianças (SOUZA; ANDRADA et al., 2013; NEVES, 2016). Na visão dos trabalhadores, estudar atende uma função pragmática que reproduz a lógica utilitária da educação pelo poder hegemônico: educar para instruir, para prevenir e para produzir (RUMMERT; ALVES, 2010).

2. A educação vem de casa e se objetiva nas produções discursivas dos espaços idealizados na relação família-escola sobre a educação. A escola é como a casa ou uma família, e os professores são como pais/mães dos alunos tratados como filhos. Associado à metáfora espacial encontra-se também o significado de educação e instrução, sendo o primeiro, prioritariamente, reservado à família. Tanto assim que os espaços e modalidades de ensino com maior grau de aprovação são os mais próximos aos cuidados parentais (QUARESMA; LOPES, 2011). A família educa e a escola instrumentaliza.

3. Educar é corrigir e disciplinar. Há uma idealização implícita no conjunto de críticas feitas pelos participantes às estratégias de controle, correção e disciplina contidas nas expressões "se comportar" e "ter educação" (OLIVEIRA; SERPE; ROSSO, 2017).

Essas representações sociais originam-se do contexto social, que abrange os meios de comunicação e ideologia circulante, o mundo do trabalho e as experiências pessoais dos participantes da pesquisa e de seus filhos com a escola. Tais fatores são atravessados por hierarquizações que se assemelham entre os grupos de trabalhadores com baixa escolarização versus escolarização superior à média nacional, podendo ser associados aos diversos níveis - econômico, cultural, moral, religioso, étnico - das comunidades a que esses trabalhadores pertencem.

O contexto da pesquisa pode ter efeito transitório e refletir a hierarquia de que se deve dizer às pessoas do universo escolar mais do que os valores reais dos 


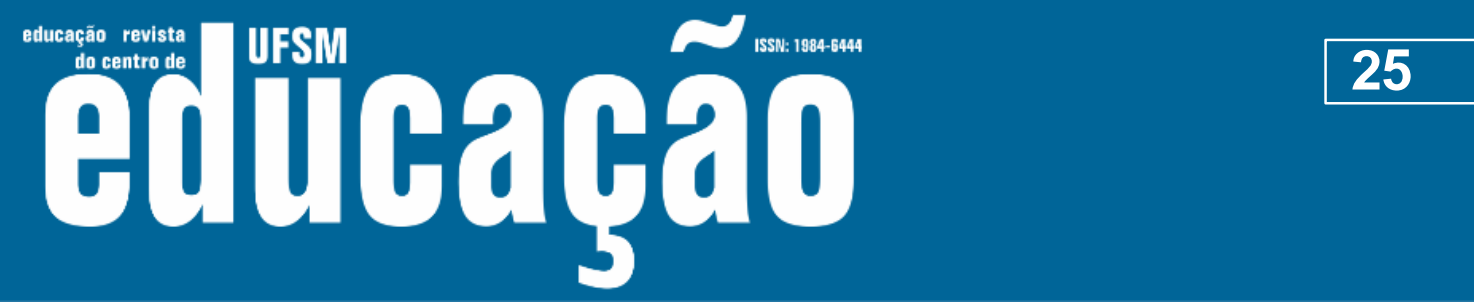

ISSN: 1984-6444 | http://dx.doi.org/10.5902/1984644432852

informantes (FLAMENT; GUIMELLI; ABRIC, 2006). Os trabalhadores com escolaridade abaixo da média, ou superior à média nacional, partilham de representações sociais que se distinguem entre eles pelo sentido com que são traduzidas a partir dos contextos dos grupos (GILLY, 2002), e as variáveis são associadas ao maior ou menor grau de vulnerabilidade social e laboral.

Para pesquisas futuras, ante as informações levantadas, permanece o desafio de uma amostra maior e do equilíbrio relacionado aos níveis de escolaridade e o sexo dos trabalhadores.

\section{Referências}

ABRIC, Jean-Claude. Abordagem estrutural das representações sociais: desenvolvimentos recentes. In: CAMPOS, Pedro Humberto Faria; LOUREIRO, Marcos Corrêa da Silva S. Representações sociais e práticas educativas. Goiânia: UCG, 2003. p. 37-57.

AFONSO, Carlos Miguel Figueiredo. O impacto do status profissional na saúde do trabalhador: uma comparação entre Brasil e Portugal. Universidade de Brasília. Brasília, p. 161. 2017.

ANTIPOFF, Renata Bastos Ferreira; FRADE, Cristina de Castro; LIMA, Francisco de Paula Antunes. Representação e prática na ação eficaz de trabalhadores pouco escolarizados da construção civil. Trabalho \& Educação, Belo horizonte, v. 25, n. 3, p. 109-126, set.-dez. 2016.

AQUINO, Juliana Maria et al. Trabalho infantil: persistência intergeracional e decomposição da incidência entre 1992 e 2004 no Brasil rural e urbano. Revista Economia de Contemporânea, Rio de Janeiro, v. 14, n. 1, p. 61-84, jan./abr. 2010.

ARANTES, Bruno Otávio; BORGES, Lívia de Oliveira. Catadores de materiais recicláveis: cadeia produtiva e precariedade. Arquivos Brasileiros de Psicologia, Rio de Janeiro, v. 65, n. 3, p. 319-337, 2013.

ARAÚJO, Ludmilla Costa Lindolfo de; SILVA, Emília Vitória da. Avaliação da adesão ao tratamento anti-hipertensivo em pacientes atendidos na Unidade de Saúde de Cocalzinho de Goiás. Tempus - Actas de Saúde Coletiva, Brasília, v. 4, n. 3, p. 8393, 2010.

BALASSIANO, Moisés; SEABRA, Alexandre Alves de; LEMOS, Ana Heloisa. Escolaridade, Salários e Empregabilidade: Tem Razão a Teoria do Capital Humano? Revista de Administração Contemporânea, v. 9, n. 4, p. 31-52, out./dez. 2005. 


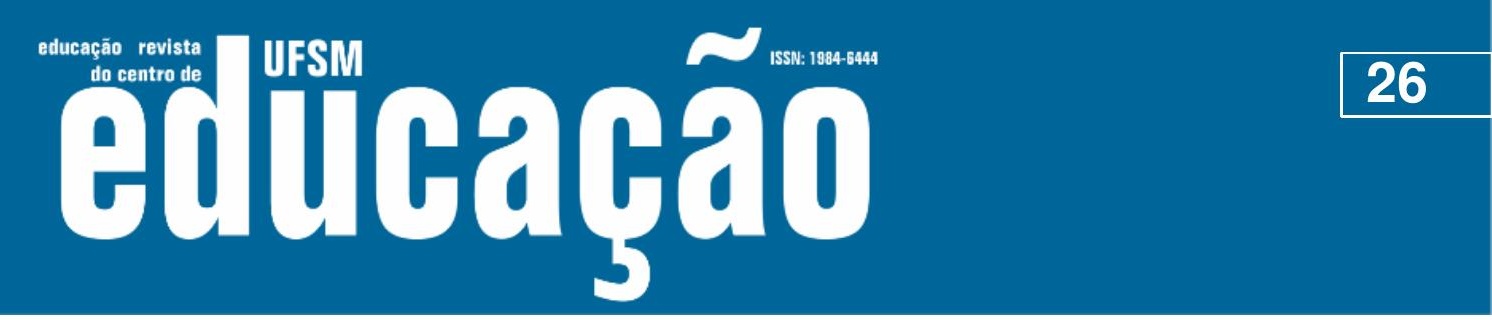

ISSN: 1984-6444 | http://dx.doi.org/10.5902/1984644432852

BELTRAMELLI NETO, Silvio; ADÃO, Felipe da Silva Pinto. Para além do ir e vir: o conceito normativo brasileiro de trabalho escravo ante o direito comparado. Revista da Faculdade de Direito UFPR, Curitiba, v. 62, n. 1, p. 113 - 136, jan./abr. 2017.

BORGES, Livia de Oliveira; PINHEIRO, José Q. Estratégias de coleta de dados com trabalhadores de baixa escolaridade. Estudos de Psicologia, v. 7, Número Especial, p. 53-63, 2002.

BRASIL. Instituto Brasileiro de Geografia e Estatística - IBGE. Síntese de Indicadores Sociais: Uma Análise das Condições de Vida da População Brasileira. Rio de Janeiro: IBGE, 2010.

BUENO, José Geraldo Silveira. Função social da escola e organização do trabalho pedagógico. Educar, Curitiba, v. 17, p. 101-110, 2001.

CALEJON, Laura Marisa Carnielo. Desempenho escolar e vulnerabilidade social. Exitus, v. 1, n. 1, p. p. 149-164, jul./dez. 2011.

CASTRO, Camila Menezes Sabino de et al. Aspectos sociodemográficos e de saúde associados ao trabalho remunerado em adultos (50-69 anos) na Região Metropolitana de Belo Horizonte, Minas Gerais, Brasil. Cadernos de Saúde Pública, Rio de Janeiro, v. 31, n. 8, p. 1775-1787, ago. 2015.

CHECHIA, Valéria Aparecida; ANDRADE, Antônio dos Santos. O desempenho escolar dos filhos na percepção de pais de alunos com sucesso e insucesso escolar. Estudos de Psicologia, v. 10, n. 3, p. 431-440, 2005.

DIOGO, Ana Matias. Famílias e escolaridade: representações parentais da escolarização, classe social e dinâmica familiar. Lisboa: Colibri, 1998

DINIZ, Michele dos Santos et al. A prática do trabalho infantil entre os beneficiários do programa bolsa-escola Belo Horizonte: um estudo sobre os determinantes sociodemográficos. Educação e Sociedade, Campinas, v. 33, n. 118, p. 149-169, jan./mar. 2012.

FERRARE, Joseph. A pesquisa educacional crítica pode ser "quantitativa"? In: APPLE, Michael Whitman; AU, Wayne.; GANDIN, Luís Armando. Educação crítica: análise internacional. Tradução de Vinícius Ferreira. Porto Alegre: Artmed, 2011. p. 512-529.

FERRARO, Alceu Ravanello. Diagnóstico da escolarização no Brasil. Revista Brasileira de Educação, n. 12, p. 22-47, set/out/nov./dez. 1999.

FLAMENT, Claude. Aspects périphériques des représentations sociales. In: ABRIC, Jean-Claude (Ed.). Pratiques sociales et représentations. Paris: Presses Universitaires de France, 1994. p. 85- 118 


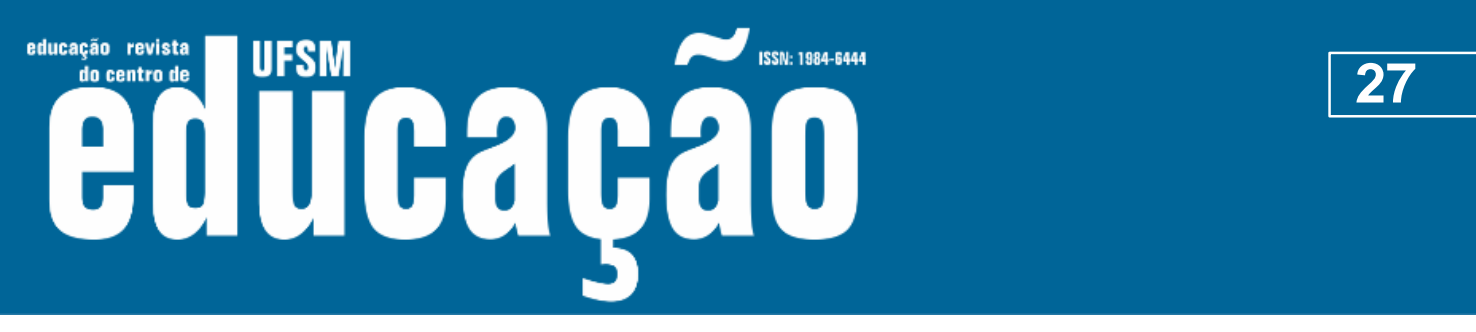

ISSN: 1984-6444 | http://dx.doi.org/10.5902/1984644432852

FLAMENT, Claude; GUIMELLI, Christian; ABRIC, Jean-Claude. Effets de masquage dans l'expression d'une représentation. Les Cahiers Internationaux de Psychologie Sociale, v. 69, p. 15-31, 2006.

GILLY, Michel. As representações sociais no campo da educação. In: JODELET, Denise. As representações sociais. Rio de Janeiro: EdUERJ, 2001. p. 321-341.

GILLY, Michel. As representações sociais no campo educativo. Educar, Curitiba, n. 19, p. 231-252, 2002.

GÓMEZ, Guillermo Stefano Rosa. Construção de identidade e trajetória social desviante: um estudo empírico com guardadores de carros em Pelotas, RS. Primeiros Estudos, São Paulo, v. 8, p. 89-104, 2017.

GUARESCHI, Pedrinho A. "Sem dinheiro não há salvação": ancorando o bem e o mal entre os neopentecostais. In: GUARESCHI, Pedrinho A.; JOVCHELOVITCH, Sandra. Textos em representações sociais. Petrópolis: Editora Vozes, 1999. p. 191-225.

JODELET, Denise. Experiência e representações sociais. In: SHIMIZU, A. M., A. M.; SHIMIZU, A. M. Experiência e representação social: questões teóricas e metodológicas. São Paulo: Casa do Psicólogo, 2005. p. 23-56.

JODELET, Denise. Imbricações entre representações sociais e intervenção. In: MOREIRA, Antonia Silva Paredes; CAMARGO, Brígido Vizeu. Contribuições para a teoria e o método de estudos das representações sociais. João Pessoa: Editora Universitária UFPB, 2007. p. 45-74.

JODELET, Denise. Problemáticas psicossociais da abordagem da noção de sujeito. Cadernos de Pesquisa, p. 314-327, 2015.

LEÃO, Geraldo; NONATO, Symaira Poliana. Políticas públicas, juventude e desigualdades sociais: uma discussão sobre o ProJovem Urbano em Belo Horizonte. Educação e Pesquisa, São Paulo, v. 38, n. 04, p. 833-848, out./dez. 2012.

LIMA, Rita de Cássia Pereira et al. Qualidade e saudosismo: representações sociais de pais sobre a escola. Psicologia da Educação, São Paulo, v. 27, n. 2, p. 31-51, 2008.

LOPES NETA, Natércia de Andrade. Democracia $X$ faz de conta: quando as condições socioeconômicas ameaçam a equipe. Educação, Cultura e Sociedade, Sinop, v. 4, n. 1, p. 86-98, jan./jun. 2014.

MARIANO, Silvana Aparecida; CARLOTO, Cássia Maria. Gênero e combate à pobreza no programa bolsa família. In: BONETTI, Alinne de Lima; ABREU, Maria Aparecida $A$. (Orgs.). Faces da desigualdade de gênero e raça no Brasil. Brasília: Ipea, 2011, p. 61-78.

MARTINEZ, Albertina Mitjáns. Trabajo Infantil y Subjetividad: una perspectiva necesaria. Estudos de Psicologia, v. 6, n. 2, p. 235-244, 2001. 


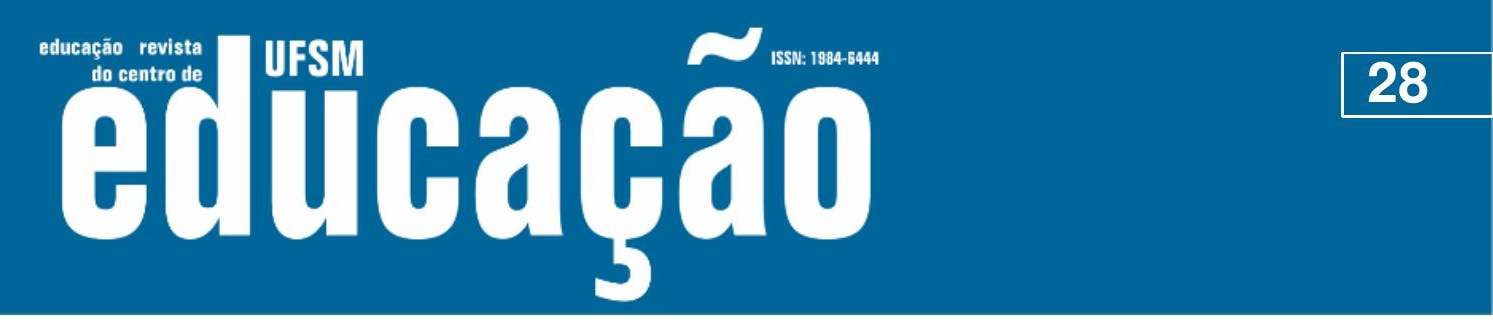

ISSN: 1984-6444 | http://dx.doi.org/10.5902/1984644432852

MARTINS, José de Souza. A valorização da escola e do trabalho no meio rural. Revista de Ciências Sociais, v. 3, n. 1, p. 19-34, 1972.

MASSON, Valéria Aparecida; MONTEIRO, Maria Innês. Vulnerabilidade a Doenças Sexualmente Transmissíveis/AIDS e uso de drogas psicoativas por caminhoneiros. Revista Brasileira de Enfermagem, Brasília, v. 63, n. 1, p. 79-83., jan.-fev. 2010.

MELO, Márcio de. Família na escola: um vínculo condizente. Revista Ciencia, Salud, Educación y economia, v. 11, p. 60-73, ene-abr 2017.

MONTEIRO, Carlos Augusto; CONDE, Wolney Lisboa; CASTRO, Inês Rugani Ribeiro de. A tendência cambiante da relação entre escolaridade e risco de obesidade no Brasil (1975-1997). Cadernos de Saúde Pública, Rio de Janeiro, v. 19, n. Sup. 1, p. S67-S75, 2003.

MOSCOVICI, Serge. Representações Sociais: investigações em psicologia social. Petrópolis: Vozes, 2003

MOSCOVICI, Serge. A psicanálise, sua imagem e seu público. Petrópolis: Vozes, 2012.

MOURA, Andréia Ferreira de; MASQUIO, Deborah Cristina Landi. A influência da escolaridade na percepção sobre alimentos considerados saudáveis. Revista de Educação Popular, Uberlândia, v. 13, n. 1, p. 82-94, jan./jun. 2014.

NAIFF, Luciene Alves Miguez; SÁ, Celso Pereira de; NAIFF, Denis Giovanni Monteiro. Preciso estudar para ser alguém: Memória e representações sociais da educação escolar. Paidéia, v. 18, n. 39, p. 125-138, 2008.

NEVES, Karina Hernandes. A educação como elemento (re)definidor da sociedade. Equidade, políticas e financiamento da educação pública. Pesquisa e debate em educação, Juiz de Fora, v. 16, n. 1, p. 93-110, 2016.

OLIVEIRA, Denise Cristina de. et al. Pedagogia, futuro e liberdade: a instituição escolar representada por professores, pais e alunos, Psicologia: Teoria e Prática, n. Edição Especial, 2004. 31-47.

OLIVEIRA, Roberval Passos de.; IRIART, Jorge Alberto Bernstein. Representações do trabalho entre trabalhadores informais da construção civil. Psicologia em Estudo, Maringá, v. 13, n. 3, p. 437-445, jul./set. 2008.

OLIVEIRA, Terezinha et al. Escola, conhecimento e formação de pessoas: considerações históricas. Políticas Educativas, Porto Alegre, v. 6, n. 2, p. 145-160, 2013.

OLIVEIRA, Vânia de. Representações Sociais da Família sobre o desenvolvimento moral de crianças e adolescentes na perspectiva da Educação. Universidade Estadual de Ponto Grossa. Ponta Grossa, p. 116. 2016. 


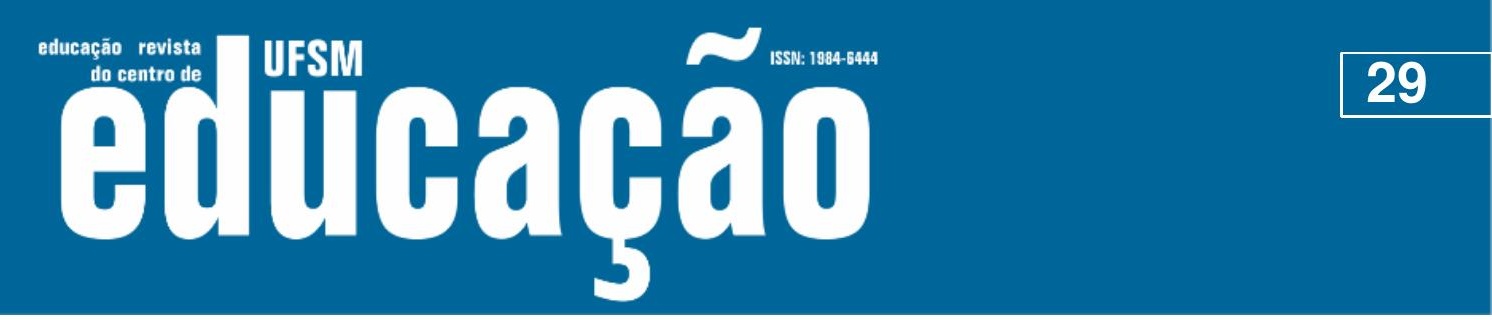

ISSN: 1984-6444 | http://dx.doi.org/10.5902/1984644432852

OLIVEIRA, Vânia de.; SERPE, Bernadete Machado; ROSSO, Ademir José. Representações sociais parentais de instituições voltadas a crianças e adolescentes atendidos em contraturno. Práxis Educativa, Ponta Grossa, v. 13, n. 1, p. 1013-1027, set./dez. 2017.

PATTO, Maria Helena Souza. Família Pobre e a Escola Pública: anotações sobre um desencontro. Psicologia USP, São Paulo, v. 3, n. 1/2, p. 107-121, 1992.

QUARESMA, Luísa; LOPES, João Teixeira. Os TEIP pela perspectiva de pais e alunos. Sociologia, Revista da Faculdade de Letras da Universidade do Porto, Porto. v. XXI, p. 141-157, 2011.

RAMOS, Natália. Espaços, culturas, identidades e saúde em comunidades marítimas e piscatórias. In: PINA, Helena.; REMOALDO, Paula; RAMOS, Conceição. The Overarching Issues of the European Space/Rethinking Socioeconomic and Environmental Problems, Repositioning Territorial Development Policies. Porto: UNIVERSIDADE DO PORTO - Faculdade de Letras da Universidade do Porto, 2016. p. 308-321.

RUMMERT, Sonia Maria.; ALVES, Natália. Jovens e adultos trabalhadores pouco escolarizados no Brasil e em Portugal: alvos da mesma lógica de conformidade. Revista Brasileira de Educação, v. 15, n. 45, p. 511-528, 2010.

SANTOS, Rúbia dos. O trabalho infantil: uma realidade que não pode ser analisada fora do contexto familiar. Katálise, Florianópolis, v. 5, n. 1, p. 67-77, jan./jun. 2002.

SERPE, Bernadete Machado. Educação, escola e instituições de contraturno social na cidade de Ponta Grossa: entrecruzamento de valores e representações por diferentes vozes. Universidade Estadual de Ponta Grossa. Ponta Grossa, p. 271. 2015.

SILVA, Nelson do Valle; HASENBALG, Carlos Tendências da Desigualdade Educacional no Brasil. Dados, Rio de Janeiro, v. 43, n. 3, p. 423-445, 2000.

SOARES, Giselle. Fruticultura no Nordeste: outras faces da opulência. Ciência e Cultura, São Paulo, v. 69, n. 2, p. 14-15, abr./jun. 2017.

SOUSA, Heloísa Nair Bicalho de. Trabalhadores pobres e cidadania. Caderno $\mathbf{C R H}$, Salvador, n. 22, p. 71-96, jan./jun. 1995.

SOUZA, Vera Lucia Trevisan de. et al. Os sentidos da escola para os pais. Psicologia da Educação, São Paulo, v. 36, n. 1 Semestre, p. 55-66, 2013.

TENORIO, Aline e Silva; COBAYASHI, Fernanda. Obesidade infantil na percepção dos pais. Revista Paulista de Pediatria, v. 29, n. 4, p. 634-9, 2011.

FORTUNATO, Luiz Henrique: VICENZI, Keli. Conhecimento sobre prática de higiene na Manipulação de alimentos em residências de Caxias do Sul - RS. Uningá Review, V.17, n.1, p.42-47, jan/mar 2014. 


\section{ح

ISSN: 1984-6444 | http://dx.doi.org/10.5902/1984644432852

TUPPY, Maria Isabel Nogueira; ARRUDA, Nanei Cestaro Dias de. Escolaridade, inserção profissional e imaginário social. Educação e Realidade, Porto Alegre, v. 30, n. 1, p. 187-200, jan./jun. 2005.

\section{Correspondência}

Ademir José Rosso - Universidade Estadual de Ponta Grossa - Campus Central Praça Santos Andrade n 1 - CEP 84.010-790 - Ponta Grossa, Paraná, Brasil.

\section{(@) $(1 \otimes$}

This work is licensed under a Creative Commons Attribution-NonCommercial 4.0 International (CC BY-NC 4.0)

\section{Agradecimento}

Ao CNPq pelo financiamento do projeto "Representações Sociais de Trabalhadores com Baixa Escolaridade sobre a Educação e o Trabalho Docente". 